\title{
Simultaneous assessement of social \\ skills and behavior problems: \\ Education and gender
}

\author{
Avaliação simultânea de habilidades sociais \\ e problemas de comportamento: \\ escolaridade e gênero
}

\author{
Alessandra Turini BOLSONI-SILVA \\ Sonia Regina LOUREIRO²
}

\begin{abstract}
The aim was to compare the social skills of preschool and school-age children, considering groups differentiated by behavior problem indicators, according to the assessment performed by parents and teachers. Children of both genders participated in this study. Parents/primary caregivers assessed 194 children and 294 children were assessed by their teachers. The results indicated that, for the parents and teachers, the children without problems were more socially skilled. The gender of the children distinguished the repertoire of social skills, according to their parents, mainly the school-age children. For the teachers, considering both school periods, girls were more socially skilled and, for both parents and teachers, boys presented more behavior problems. These data have implications for assessment and intervention procedures.
\end{abstract}

Keywords: Behavior problems; Children preschool; Social skills; Students.

\section{Resumo}

Objetivou-se comparar as habilidades sociais de crianças pré-escolares e escolares considerando grupos diferenciados por problemas de comportamento e gênero, tendo por referência as avaliações de pais e professores. Participaram crianças de ambos os sexos, 194 avaliadas por pais/cuidadores primários e 294 por professores, dos períodos pré-escolar e escolar. Os resultados indicaram que para pais e professores as crianças sem problemas são mais habilidosas, tanto na pré-escola como na idade escolar. O gênero das crianças diferenciou o repertório de habilidades sociais, segundo os pais, para escolares. Para os professores, em ambos os períodos escolares as meninas foram mais habilidosas e, para pais e professores, os meninos apresentaram mais problemas de comportamento. Esses dados têm implicações para procedimentos de avaliação e intervenção.

Palavras-chave: Problemas de comportamento; Pré-escolar; Habilidades sociais; Estudantes.

$\because N$

1 Universidade Estadual Paulista, Faculdade de Ciências, Departamento de Psicologia. Av. Eng. Luiz Edmundo Carrijo Coube, 14-01, Vargem Limpa, 17033-360, Bauru, SP, Brasil. Correspondência para/Correspondence to: A.T. BOLSONI-SILVA. E-mail: <bolsoni@fc.unesp.br>.

${ }^{2}$ Universidade de São Paulo, Faculdade de Medicina, Departamento de Neurociências e Ciências do Comportamento. Ribeirão Preto, SP, Brasil.

Support: Conselho Nacional de Desenvolvimento Cientifico e Tecnológico (Process n 301303/2012-6 and 307394/2014-0). 
The study of social skills in preschool and school-age children is justified by survey data that consistently points to an inverse relationship between this repertoire and behavior problems in this population (Barham \& Cia, 2009; Barreto, Freitas, \& Del Prette, 2011; Berry \& O'Connor, 2010; Bolsoni-Silva, Marturano, \& Loureiro, 2011; Kim, Doh, Hong, \& Choi, 2010; Leme \& Bolsoni-Silva, 2010; Reynolds, Sander, \& Irvin, 2010). Thus, skilled social behaviors can be considered inversely proportional to behavior problems (Kettler, Elliott, Davies, \& Griffin, 2011; Miner, \& Clarke-Stewart, 2008; Pizato, Marturano, \& Fontaine, 2014).

Behavior problems, in turn, can be externalizing, that is, they lead to conflicts in the environment and are generally characterized by challenging features such as impulsivity, aggression, hyperactivity and poor adjustment; internalizing problems are related to personal disorders such as anxiety, withdrawal, depression and feelings of inferiority (Achenbach \& Rescorla, 2001). In general, externalizing behavior problems motivate the search for psychological care because complain parents more frequently that they cause greater discomfort in social interactions, as well as other complaints such as behavior and learning problems, particularly in preschool children (Lambert, Wahler, Andrade, \& Bickman, 2001; Melo \& Perfeito, 2006; Scortegagno \& Levandowski, 2004; Wielewicki, 2011) and boys (Landale, Lanza, Hillemeier, \& Oropesa, 2013; Massola \& Silvares, 2005; Olson \& Hoza, 1993; Samarakkody, Fernando, McClure, Perera, \& De Silva, 2012). Two variables, education and gender of children, have been the subject of several studies, but the results have not always been in agreement.

Regarding the years of education of children, a diversity of social skills and behavior problems have been found, which are in a way related to the demands of acquisition and performance that vary depending on the stages of development. Previous studies have found that school-age children are more socially skilled than preschool children (Berry \& O'Connor, 2010; Bolsoni-Silva, Marturano, \& Freiria, 2010; Konold, Jamison, Stanton-Chapman,
\& Rimm-Kaufman, 2010), who tend to present more behavior problems (Bolsoni-Silva et al., 2010; Karp, Serbin, Stack, \& Schwartzman, 2004). However, when studying children in the $1^{\text {st }}$ to $4^{\text {th }}$ grade using a self-assessment test, Bandeira, Rocha, Freitas, Del Prette and Del Prette (2006a) reported that the older the child, the lower was their overall social skill score. These authors argued that these findings may be due to the child's self perception, rather than their repertoire of social skills.

There is also no consensus in the literature regarding the data on the variable gender and behavior problems. Some studies have found that boys have more behavior problems, especially externalizing ones (Bandeira et al., 2006a; Cosentino-Rocha \& Linhares, 2013; Olson \& Hoza, 1993), while girls have more internalizing problems (Cosentino-Rocha \& Linhares, 2013; Olson \& Hoza, 1993). However, Massola and Silvares (2005), in agreement with other studies, did not find any differences in externalizing and internalizing problems when evaluating boys and girls from the point of view of teachers and parents using the instruments Child Behavior Checklist $(\mathrm{CBCL})$ and Teachers Report Form (TRF). With respect to social skills, studies have shown that girls have higher scores and more skills (Bandeira et al., 2006a; Leman \& Björnberg, 2010), such as taking initiative, expressing opinions (Bolsoni-Silva, Marturano, \& Manfrinato, 2005) and communicating (Leman \& Björnberg, 2010).

Another important aspect to consider when referring to data on the assessment of children's behavior is who the evaluator was, i.e. the context used as reference during the assessment. Thus, some studies have found that mothers and teachers have different relationships with children, which certainly influences how they assess their behavior (Konold et al., 2010; Satake, Yoshida, Yamashita, Kinukawa, \& Takagishi, 2003). Although the relevance of these two evaluators is not ruled out (Bolsoni-Silva, Marturano, Pereira, \& Manfrinato, 2006), a multimodal assessment is needed to better understand the children's behaviors (Barreto et al., 2011; Konold et al., 2010). 
From the point of view of preschool mothers, the most frequent social skills in children without behavior problems are as follows: expressing frustrations, playing with peers, expressing wishes, expressing rights, being in a good mood, seeking attention, communicating (Bolsoni-Silva et al., 2005), expressing affection, criticizing (Leme \& Bolsoni-Silva, 2010) and the overall score (Bolsoni-Silva et al., 2011). As for the teachers of pre-school children without behavior problems the most frequent skills are as follows: seeking attention, expressing frustrations, communicating, being in a good mood (Bolsoni-Silva et al., 2011), seeking help, greeting people, praising, taking initiative, expressing desires, affection, expressing rights, interacting nonverbally (Bolsoni-Silva et al., 2006), playing with colleagues, showing concern for others, participating in play groups, participating in discussions, helping others, expressing opinions, negotiating and convincing, speaking, taking initiative, expressing frustrations, and greeting (Bolsoni-Silva, Marturano, \& Loureiro, 2009).

Analyzing the literature, a diversity of data was found regarding the peculiarities of social skills and behavior problems when assessing children differentiated by schooling and gender using the family and teachers as informants. However, we have not found any studies that simultaneously approached all these variables, considering the assessments of teachers and family in a single sample. We believe that measures assessed simultaneously can help elucidate the lack of agreement on the influence of gender and schooling in the children's repertoire. Thus, there is a lack of studies that use simultaneous assessments of social skills and behavior problems assessed by parents/ mothers/caregivers and teachers of preschool and school-age boys and girls.

The present study intends to fill this gap, aiming to compare the social skills of preschool and school-age children by considering groups differentiated by behavior problem indicators and gender using the assessment of parents and teachers as a reference.

\section{Method}

\section{Participants}

The study included teachers and mothers/ parents/caregivers of preschool and school-age children. Not all children were assessed at home and in the school environment. Parents assessed 95 preschool children (54 boys and 41 girls) and 99 school-age children (61 boys and 38 girls), totaling 194 children. The teachers assessed 126 preschool children (62 boys and 64 girls) and 168 school-age children (116 boys and 52 girls), totaling 294 children. Preschool and school-age children were divided into clinical and non-clinical groups, according to the point of view of the mothers/ parents/caregivers and teachers. If the child scored in at least one of the scales (overall score, internalizing, externalizing problems) of the $\mathrm{CBCL}$ or TRF instruments, then the child would be placed in the clinical group.

The mean age of preschool children was four years (Standard Deviation - SD $=1.09$ ) and the mean age of the school-age children was 8 years $(S D=1.84)$. The mean age of preschool teachers was 43 years $(S D=8.04)$ and the mean age of teachers of school-age children was 36 years $(S D=9.48)$.

The mean age of family respondents was 33 years $(S D=7.95)$. The demographic characteristics of family caregivers were as follows: (a) $83.3 \%$ mothers, $7.1 \%$ fathers and $7.0 \%$ caregivers; (b) $78.0 \%$ of the families reported being in a stable relationship, $11.9 \%$ were single, $8.0 \%$ widowed and $8.7 \%$ divorced; (c) with regard to years of education, $36.0 \%$ of the sample stated to have primary education (complete or incomplete), $46.0 \%$ high school education (complete or incomplete), and $17.4 \%$ college education (complete or incomplete); (d) $50.8 \%$ of the family sample have a job; (e) regarding family income in minimum wages, the data were: $13.5 \%$ reported earning one minimum wage; $27.8 \%$ two minimum wages; $27.0 \%$ three minimum wages; $11.9 \%$ four minimum wages; $10.3 \%$ five minimum wages; and $8.8 \%$ above six minimum wages. 


\section{Instruments}

The Child Behavior Checklist and Teachers Report Form (Behavior Inventories for Children and Adolescents, Achenbach \& Rescorla, 2001) for preschool and school-age children (4-18 years) investigate, in a diagnostic manner according to the reports of parents and teachers, the frequency of 113 responses indicative of behavior problems. The results are organized according to the instrument scales. The instruments also assess academic performance of school-age children. The consistency index of the complete CBCL scale is $0.92,0.88$ for externalizing problems and 0.80 for internalizing problems. In the TRF, the alpha on the complete scale was $0.90,0.88$ for externalizing problems and 0.80 for internalizing problems. When assessing the clinical and non-clinical profiles, Bordin, Mari, and Caeiro (1995) found satisfactory criteria of test positivity and morbidity.

The Questionnaire of Socially Skilled Response for Parents (QRSH-Parents) assesses the frequency of 18 socially skilled responses, according to the fathers' and mothers' reports (Bolsoni-Silva et al., 2011) and the Questionnaire of Socially Skilled Response for Teachers (QRSH-T) assesses 24 socially skilled responses, according to the teachers' report; the items are distributed into three factors: sociability and emotional expressiveness, social initiative, and search for support (Bolsoni-Silva et al., 2009). The QRSH-Parents presented satisfactory discriminative and concurrent validity and an alpha value of 0.82 (Bolsoni-Silva et al., 2011). The QRSH-T showed satisfactory discriminative, concurrent and predictive validity and an alpha value of 0.93 (Bolsoni-Silva et al., 2009). Although the QRSH-T instrument has a distribution of items by factors, we chose to work with the items to facilitate comparisons with the parents' version and thus be able to make more specific comparisons of the indicators.

\section{Procedures}

Before starting data collection, we obtained 456 approval from the Department of Early Childhood
Education from a city in the state of São Paulo. In the second stage, we contacted preschools and elementary schools to check availability to participate in the study.

Data were collected from 14 municipal preschools and 12 elementary schools and from families who agreed to participate. The director or the pedagogical coordinator of the school was informed of the objectives and methods of the research, which were then explained to the teachers interested in participating. The teachers who agreed to participate signed a term of free and informed and suggested two children, one who they considered having behavior problems and one without behavior problems. The teachers answered the instruments for both children.

After this stage, we contacted the families of the children suggested by the teachers, who were then invited to participate in the study and the study objectives were explained to them. Mothers who agreed to participate signed a term of free and informed consent and answered the $\mathrm{CBCL}$ as an interview format, which was conducted at a place of their choice (at their home or at school). Both schools and families were given information materials on the subject after the end of data collection. Informative lectures were delivered at schools to the teachers if requested, covering various aspects of child development. Data were collected between the years 2010 and 2012 with 112 teachers, who evaluated 294 children, and 194 mothers/parents/caregivers.

The tabulation sequence of the data was as follows: (a) data entry into the Aseba software to encode the behavior of children from the TRF and $C B C L$ instruments in all categories; (b) organization of participants into groups according to gender and with or without behavior problems. The reference for the classification was the information obtained through the TRF and CBCL (scales of internalizing, externalizing problems and overall problems in both scales) so for a given child to be considered as having a problem, his/her behavior should have been assessed as a clinical or borderline in at least one of the scales; for children to be considered without behavior problems they could not have been 
assessed as borderline in any of these three scales; (c) using Student's t-test, we compared the social skills according to behavior problems (presence $X$ absence) and gender, taking into consideration the assessments of the parents/carergivers and teachers, and the distribution of preschool and school-age children; (d) the Chi-square test produced by Crosstabs was calculated to verify the distribution of boys and girls in the groups with and without a problem for preschool and school-age children from the point of view of parents/caregivers and teachers; (e) the Chi-square test produced by Crosstabs was calculated to verify the distribution of preschool and school-age children in the groups with and without problems. The results were organized in tables and figures and a 5\% significance level was adopted.

The study was approved by the Research Ethics Committee of the Universidade Estadual Paulista. It is part of a larger project entitled "Health, Marital Social Skills and Parental Education: A comparison of education, gender and behavior problems" (Process n 5826/46/01/10).

\section{Results}

The results section is organized according to the objectives for the comparison of social skills of preschool and school-age children, differentiated by behavior problems and gender from the parents' (Table 1) and teachers' reports (Tables 2, 3, 4 and 5).

According to Table 1, comparisons between the groups with or without problems were first described, followed by the description related to gender. From the point of view of the primary caregivers, we noted that the overall score of social skills of preschool children and seven of the items assessed by the instrument (making friends, praising, positive communication, expressing rights and needs, negotiating and convincing and usually being in a good mood) were different in the clinical and non-clinical groups. The highest mean values were found in the non-clinical group. The results for the school-age children were similar. The highest mean scores in the overall score and five of the items

Table 1

Assessment of social skills (HS) of preschool children ( $N=95)$ and school-age children $(N=99)$, according to the report of parents, differentiated by the presence of behavior problem indicators and gender. São Paulo, SP, 2013

\begin{tabular}{|c|c|c|c|c|c|c|}
\hline \multirow{2}{*}{ SS - QRSH-Parents preschool } & \multicolumn{2}{|c|}{ Problems $(n=46)$} & \multicolumn{2}{|c|}{ Without problems $(n=49)$} & \multirow{2}{*}{$t$} & \multirow{2}{*}{$p$} \\
\hline & $M$ & $S D$ & $M$ & $S D$ & & \\
\hline Making friends & 1.72 & 0.54 & 1.92 & 0.28 & -2.290 & $0.024^{*}$ \\
\hline Praising & 1.50 & 0.75 & 1.80 & 0.50 & -2.271 & 0.025 \\
\hline Positive communication & 1.70 & 0.55 & 1.94 & 0.24 & -2.807 & 0.006 \\
\hline Expressing needs and rights & 1.33 & 0.79 & 1.67 & 0.52 & -2.552 & 0.012 \\
\hline Negotiating and convincing & 1.09 & 0.89 & 1.53 & 0.65 & -2.788 & 0.006 \\
\hline Total score & 28.45 & 7.26 & 32.27 & 3.12 & -3.372 & 0.001 \\
\hline SS - QRSH-Parents preschool & \multicolumn{2}{|c|}{ Boys $(n=54)$} & \multicolumn{2}{|c|}{ Girls $(n=41)$} & & \\
\hline Usually being in a good mood & 1.67 & 0.61 & 1.93 & 0.26 & -2.538 & 0.013 \\
\hline Negotiating and convincing & 1.17 & 0.82 & 1.51 & 0.75 & -2.144 & 0.037 \\
\hline SS - QRSH-Parents school-age & \multicolumn{2}{|c|}{ Problems ( $n=53)$} & \multicolumn{2}{|c|}{ Without problems $(n=46)$} & & \\
\hline Expressing frustration & 1.30 & 0.87 & 1.61 & 0.61 & -2.002 & 0.048 \\
\hline Praising & 1.53 & 0.75 & 1.78 & 0.47 & -1.989 & 0.049 \\
\hline Expressing desires and preferences & 1.55 & 0.75 & 1.80 & 0.40 & -2.084 & 0.040 \\
\hline Taking initiative & 1.30 & 0.70 & 1.67 & 0.63 & -2.782 & 0.006 \\
\hline Usually being in a good mood & 1.62 & 0.60 & 1.87 & 0.40 & -2.382 & 0.019 \\
\hline Overall score & 29.30 & 6.00 & 31.74 & 4.00 & -2.409 & 0.018 \\
\hline
\end{tabular}

Note: * Results with statistical significance.

M: Mean; SD: Standard Deviation; SS - QRSH-Parents: Social Skills - Questionnaire of Socially Skilled Response for Parents. 
assessed (expressing frustration, praising, expressing wishes and preferences, taking initiative, usually being in a good mood) were found in the nonclinical group. It is interesting to note that praising and being in a good mood was common for preschool and school-age children, suggesting that these behaviors are important during these two stages of development.

We noted that behaviors of pre-school children such as negotiating, positive communication, being affectionate and expressing rights were important to distinguish children with and without problems. The items expressing frustration, taking initiative and expressing desires and preferences in the school-age stage distinguished these groups. Anyhow, it must be stated that most of the items assessed did not distinguish the groups, although the overall score did, indicating that the group with behavior problems, from the point of view of parents/mothers/caregivers, showed a good repertoire of social skills, although the children presented the previously described deficits.

When comparing gender, only the items that assessed preschool children (usually being in a good mood; negotiating and convincing) differentiated the groups. It was found that gender, from the point of view of fathers/mothers/caregivers, little interfered with the social skill scores.

Additionally, a Chi-square analysis was conducted and we found that girls and boys are differently distributed between the groups with and without problems for both preschool children (with problems: 33 boys and 15 girls; without problems: 21 boys and 27 girls) and school-age children (with problems: 39 boys and 16 girls, without problems: 22 boys and 22 girls $)\left(\chi^{2}=6.095, p=0.014 ; \chi^{2}=4.519\right.$, $p=0.034$, respectively).

As shown in Table 2, we noted that in preschool children, from the teachers' point of view, the overall score of social skills and 21 of the 24

Table 2

Assessment of social skills of preschool children, from the point of view of teachers, differentiated by the presence of behavior problems indicators (N = 126). São Paulo, SP, 2013

\begin{tabular}{|c|c|c|c|c|c|c|}
\hline \multirow{2}{*}{ SS - QRSH-T preschool } & \multicolumn{2}{|c|}{ Problems $(\mathrm{n}=57)$} & \multicolumn{2}{|c|}{ Without problems $(n=69)$} & \multirow{2}{*}{$t$} & \multirow{2}{*}{$p$} \\
\hline & $M$ & $S D$ & $M$ & $S D$ & & \\
\hline Helping & 1.28 & 0.86 & 1.87 & 0.38 & -5.113 & $0.000^{*}$ \\
\hline Making friends & 1.53 & 0.60 & 1.90 & 0.39 & -4.193 & 0.000 \\
\hline Nonverbal interaction & 1.47 & 0.71 & 1.84 & 0.47 & -3.463 & 0.001 \\
\hline Asking questions & 1.39 & 0.84 & 1.71 & 0.64 & -2.451 & 0.016 \\
\hline Being in positive relationships & 1.19 & 0.83 & 1.81 & 0.52 & -5.079 & 0.000 \\
\hline Expressing frustration & 0.72 & 0.80 & 1.81 & 0.46 & -9.605 & 0.000 \\
\hline Not being intimidated & 0.86 & 0.93 & 1.26 & 0.78 & -2.629 & 0.010 \\
\hline Playing with colleagues & 1.67 & 0.61 & 1.90 & 0.35 & -2.681 & 0.008 \\
\hline Praising & 0.82 & 0.91 & 1.49 & 0.74 & -4.550 & 0.000 \\
\hline Expressing desires, preferences & 1.00 & 0.79 & 1.81 & 0.49 & -6.975 & 0.000 \\
\hline Expressing care & 1.11 & 0.77 & 1.84 & 0.47 & -6.561 & 0.000 \\
\hline Communicating & 1.37 & 0.72 & 1.86 & 0.43 & -4.682 & 0.000 \\
\hline Expressing rights, needs & 1.00 & 0.80 & 1.72 & 0.59 & -5.831 & 0.000 \\
\hline Usually being in a good mood & 1.28 & 0.80 & 1.96 & 0.21 & -6.787 & 0.000 \\
\hline Expressing opinions & 1.26 & 0.88 & 1.64 & 0.64 & -2.765 & 0.007 \\
\hline Negotiating and convincing & 0.80 & 0.90 & 1.20 & 0.83 & -2.567 & 0.011 \\
\hline Participating in play groups & 1.61 & 0.62 & 1.84 & 0.50 & -2.264 & 0.025 \\
\hline Participating in discussions & 1.16 & 0.84 & 1.65 & 0.66 & -3.696 & 0.000 \\
\hline Showing interest for others & 0.79 & 0.80 & 1.65 & 0.66 & -6.651 & 0.000 \\
\hline Overall score & 28.58 & 12.13 & 40.64 & 8.11 & -6.652 & 0.000 \\
\hline
\end{tabular}

Note: *Results with statistical significance. 
items assessed differentiated the groups with and without problems. The highest mean value was found in the group without problems for items: making friends, greeting people, having positive relationships, helping, taking initiative, expressing opinions, asking questions, and not being intimidated.

The results for school-age children were similar to those obtained for preschool children. From the teachers' point of view, the overall score of social skills and 21 of the 24 items assessed differentiated the clinical from the non-clinical groups. The highest mean values in the non-clinical group were found for items: making friends, greeting people, having positive relationships, helping, taking initiative, expressing opinions, making requests, and asking questions. Therefore, unlike the assessments of fathers/mothers/ caregivers, most of the assessed items equally differentiated the pre-school and school-age groups, indicating that more years of education little differentiated the groups from the point of view of the repertoire of social skills.

As shown in Table 4, in accordance with the teachers, the overall score and $62.5 \%$ of the items distinguished preschool children according to gender. The groups were differentiated by various items such as greeting people, having positive relationships, expressing frustration, helping, taking initiative, participating in discussion.

The Chi-square analysis showed that preschool girls and boys are distributed differently between the groups with and without problems (with problems, 41 boys and 16 girls; without problems, 21 boys and 48 girls $\left(\chi^{2}=21.404, p=0.000\right)$.

Table 5 shows that the overall score and $66.6 \%$ of the items from the QRSH-T instrument differentiated school-age children according to gender. Examples of the items are as follows:

Table 3

Assessment of social skills of school-age children, from the point of view of teachers, differentiated by the presence of behavior problems indicators ( $N=168)$. São Paulo, SP, 2013

\begin{tabular}{|c|c|c|c|c|c|c|}
\hline \multirow{2}{*}{ SS - QRSH-T school-age } & \multicolumn{2}{|c|}{ Problems $(n=86)$} & \multicolumn{2}{|c|}{ Without problems $(n=82)$} & \multirow{2}{*}{$t$} & \multirow{2}{*}{$p$} \\
\hline & $M$ & $S D$ & $M$ & $S D$ & & \\
\hline Making requests & 1.20 & 0.79 & 1.45 & 0.72 & -2.184 & $0.030^{*}$ \\
\hline Helping & 1.17 & 0.81 & 1.95 & 0.22 & -8.358 & 0.000 \\
\hline Making friends & 1.57 & 0.64 & 1.90 & 0.38 & -4.172 & 0.000 \\
\hline Nonverbal interaction & 1.56 & 0.64 & 1.90 & 0.34 & -3.606 & 0.000 \\
\hline Greeting & 1.08 & 0.86 & 1.84 & 0.43 & -7.213 & 0.000 \\
\hline Positive relationships & 1.21 & 0.77 & 1.90 & 0.30 & -7.633 & 0.000 \\
\hline Expressing frustration & 0.77 & 0.81 & 1.65 & 0.62 & -7.907 & 0.000 \\
\hline Playing with colleagues & 1.67 & 0.62 & 1.84 & 0.48 & -1.937 & 0.054 \\
\hline Praising & 0.72 & 0.81 & 1.59 & 0.67 & -7.556 & 0.000 \\
\hline Expressing desires, preferences & 1.08 & 0.87 & 1.83 & 0.47 & -7.255 & 0.000 \\
\hline Expressing care & 1.27 & 0.74 & 1.77 & 0.53 & -5.017 & 0.000 \\
\hline Communicating & 1.26 & 0.69 & 1.90 & 0.30 & -7.824 & 0.000 \\
\hline Expressing rights, needs & 0.95 & 0.82 & 1.85 & 0.39 & -8.977 & 0.000 \\
\hline Being in a good mood & 1.36 & 0.72 & 1.93 & 0.26 & -6.727 & 0.000 \\
\hline Expressing opinions & 1.35 & 0.79 & 1.84 & 0.40 & -5.044 & 0.000 \\
\hline Participating in play groups & 1.33 & 0.73 & 1.93 & 0.31 & -6.930 & 0.000 \\
\hline Participating in discussions & 0.91 & 0.86 & 1.83 & 0.44 & -8.669 & 0.000 \\
\hline Speaking up & 1.22 & 0.86 & 1.59 & 0.68 & -3.901 & 0.000 \\
\hline Showing interest & 0.87 & 0.73 & 1.79 & 0.44 & -9.834 & 0.000 \\
\hline Overall score & 28.72 & 11.30 & 41.56 & 5.99 & -9.135 & 0.000 \\
\hline
\end{tabular}

Note: *Results with statistical significance.

M: Mean; SD: Standard Deviation; SS - QRSH-T: Social Skills - Questionnaire of Socially Skilled Response for Teachers. 
greeting people, having positive relationships, expressing frustration, helping, taking initiative, participating in discussion. It may be concluded that, from the teachers' point of view, gender interfered in the social skill scores for preschool and schoolage children.

In addition, a Chi-square analysis was conducted and we noted that among school-age

Table 4

Assessment of social skills of school-age children, from the point of view of teachers, differentiated by gender ( $N=126)$. São Paulo, SP, 2013

\begin{tabular}{|c|c|c|c|c|c|c|}
\hline \multirow{2}{*}{ SS - QRSH-T preschool } & \multicolumn{2}{|c|}{ Boys $(n=62)$} & \multicolumn{2}{|c|}{ Girls $(n=64)$} & \multirow{2}{*}{$t$} & \multirow{2}{*}{$p$} \\
\hline & $M$ & $S D$ & $M$ & $S D$ & & \\
\hline Helping & 1.44 & 0.78 & 1.77 & 0.58 & -2.692 & $0.008^{*}$ \\
\hline Greeting & 1.19 & 0.88 & 1.59 & 0.68 & -2.848 & 0.000 \\
\hline Positive relationships & 1.31 & 0.86 & 1.75 & 0.53 & -3.487 & 0.001 \\
\hline Expressing frustration & 1.08 & 0.86 & 1.55 & 0.75 & -3.242 & 0.002 \\
\hline Not being intimidated & 0.87 & 0.91 & 1.28 & 0.79 & -2.704 & 0.008 \\
\hline Praising & 0.98 & 0.90 & 1.39 & 0.83 & -2.644 & 0.009 \\
\hline Expressing desires, preferences & 1.13 & 0.83 & 1.76 & 0.53 & -5.076 & 0.000 \\
\hline Taking initiative & 1.44 & 0.76 & 1.72 & 0.58 & -2.362 & 0.020 \\
\hline Expressing care & 1.27 & 0.77 & 1.73 & 0.60 & -3.749 & 0.000 \\
\hline Communicating & 1.47 & 0.69 & 1.80 & 0.51 & -3.039 & 0.003 \\
\hline Expressing rights, needs & 1.15 & 0.81 & 1.64 & 0.68 & -3.743 & 0.000 \\
\hline Usually being in a good mood & 1.53 & 0.74 & 1.77 & 0.53 & -2.044 & 0.043 \\
\hline Participating in play groups & 1.63 & 0.66 & 1.84 & 0.44 & -2.151 & 0.033 \\
\hline Participating in discussions & 1.19 & 0.83 & 1.66 & 0.67 & -3.453 & 0.001 \\
\hline Showing interest for others & 1.03 & 0.85 & 1.48 & 0.78 & -3.117 & 0.002 \\
\hline Overall score & 31.50 & 12.26 & 38.75 & 10.10 & -3.627 & 0.000 \\
\hline
\end{tabular}

Note: ${ }^{*}$ Results with statistical significance.

M: Mean; SD: Standard Deviation; SS - QRSH-T: Social Skills - Questionnaire of Socially Skilled Response for Teachers.

Table 5

Assessment of social skills of school-age children, from the point of view of teachers, differentiated by gender (N = 168). São Paulo, SP, 2013

\begin{tabular}{|c|c|c|c|c|c|c|}
\hline \multirow{2}{*}{ SS - QRSH-T school-age } & \multicolumn{2}{|c|}{ Boys $(n=116)$} & \multicolumn{2}{|c|}{ Girls $(n=52)$} & \multirow{2}{*}{$t$} & \multirow{2}{*}{$p$} \\
\hline & $M$ & $S D$ & $M$ & $S D$ & & \\
\hline Helping & 1.43 & 0.74 & 1.79 & 0.61 & -2.912 & $0.004^{*}$ \\
\hline Nonverbal interaction & 1.62 & 0.59 & 1.87 & 0.40 & -3.036 & 0.003 \\
\hline Greeting & 1.32 & 0.82 & 1.75 & 0.59 & -3.415 & 0.001 \\
\hline Positive relationships & 1.41 & 0.72 & 1.85 & 0.46 & -3.964 & 0.000 \\
\hline Expressing frustration & 1.08 & 0.85 & 1.44 & 0.77 & -2.665 & 0.009 \\
\hline Praising & 0.93 & 0.85 & 1.61 & 0.66 & -5.138 & 0.000 \\
\hline Expressing desires, preferences & 1.33 & 0.80 & 1.71 & 0.61 & -3.087 & 0.002 \\
\hline Taking initiative & 1.32 & 0.82 & 1.73 & 0.56 & -3.289 & 0.001 \\
\hline Expressing care & 1.38 & 0.74 & 1.80 & 0.44 & -3.861 & 0.000 \\
\hline Communicating & 1.46 & 0.65 & 1.83 & 0.47 & -3.681 & 0.000 \\
\hline Expressing rights, needs & 1.23 & 0.82 & 1.75 & 0.59 & -4.109 & 0.000 \\
\hline Usually being in a good mood & 1.56 & 0.65 & 1.81 & 0.49 & -2.452 & 0.015 \\
\hline Expressing opinions & 1.50 & 0.70 & 1.79 & 0.57 & -2.595 & 0.010 \\
\hline Participating in play groups & 1.53 & 0.68 & 1.81 & 0.49 & -2.617 & 0.010 \\
\hline Participating in discussions & 1.19 & 0.84 & 1.73 & 0.66 & -4.095 & 0.000 \\
\hline Showing interest for others & 1.16 & 0.79 & 1.67 & 0.55 & -4.207 & 0.000 \\
\hline Overall score & 32.81 & 11.25 & 39.85 & 9.23 & -3.950 & 0.000 \\
\hline
\end{tabular}

Note: *Results with statistical significance.

460 M: Mean; SD: Standard Deviation; SS - QRSH-T: Social Skills - Questionnaire of Socially Skilled Response for Teachers. 
children, girls and boys were distributed differently between the groups with and without problems (with problem, 73 boys and 13 girls; without problems, 43 boys and 39 girls $)\left(\chi^{2}=26.482, p=0.000\right.$, respectively). The Chi-square analysis between behavior problems and years of education from the point of view of fathers/mothers/caregivers and teachers did not differentiate the clinical and nonclinical groups ( $p=0.523, p=0.312$, respectively).

\section{Discussion}

In general, the results indicated that, according to parents and teachers, preschool and school-age children without problems are more socially skilled, corroborating other studies (Bandeira, Rocha, Souza, Del Prette, \& Del Prette, 2006b; Barham \& Cia, 2009; Barreto et al., 2011; Berry \& O'Connor, 2010; Bolsoni-Silva et al., 2011; Kim et al., 2010; Leme \& Bolsoni-Silva, 2010).

Considering the simultaneous assessments of fathers/mothers/caregivers and teachers, we cannot affirm that preschool children are more socially skilled than school-age children, which is not in agreement with the literature (Berry \& O'Connor, 2010; Bolsoni-Silva et al., 2010; Konold et al., 2010) because the overall scores of social skills and the similar number of items distinguished preschool and school-age children in different areas of social skills, such as civility, communication, affection and coping (Bolsoni-Silva et al., 2005; Bolsoni-Silva et al., 2011). We did not confirm the findings that show that preschool children have more behavior problems (Bolsoni-Silva et al., 2010; Karp et al., 2004) in accordance with the reports of fathers/mothers/caregivers and teachers.

When fathers/mothers/caregivers were informants, we noted that children in different school stages presented some common areas of social skills (praising and being in a good mood) and other different ones such as negotiating, communicating, being affectionate and expressing rights during the preschool stage and frustration, taking initiative and expressing desires and preferences during the school stage. Other studies have also found that these skills differentiate preschool children with and without problems (Bolsoni-Silva et al., 2011; Leme \& Bolsoni-Silva, 2010), but the items praising and negotiating were identified only in the present research. Furthermore, data on other skills (expressing wishes, playing and seeking attention) that distinguished children in previous studies (Bolsoni-Silva et al., 2011; Leme \& Bolsoni-Silva, 2010) were not confirmed in the present study.

One possible explanation for these differences may have been due to the use of diagnostic tools in the present study, while the above-mentioned studies used tracking tools. We must point out that this finding also indicates that the quantity and intensity of problems can interfere with areas of social skills and these must be the focus of a possible intervention. From the point of view of teachers of preschool and school-age children, most items distinguished the groups of children with behavior problems (Bolsoni-Silva et al., 2009; Bolsoni-Silva et al., 2011).

The gender of children little distinguished the repertoire of social skills from the parent's point of view, which is in agreement with Massola and Silvares (2005) and, in part, with Bolsoni-Silva et al. (2005). It is noteworthy that among students, the item taking initiative was discriminative in the present study and in the study of Bolsoni-Silva et al. (2005). Other items identified in preschool (negotiating and being in a good mood) and schoolage children (expressing affection) were not documented in other studies, suggesting that they are behaviors that one should be aware of when assessing boys and girls. According to teachers of preschool and school-age children, girls were more skilled than boys, which corroborates other studies (Bandeira et al., 2006a; Bolsoni-Silva et al., 2005; Leman \& Björnberg, 2010).

With regard to behavior problems, parents and teachers were in agreement that preschool and school-age boys present more behavior problems (Bandeira et al., 2006b; Cosentino-Rocha \& Linhares, 2013; Olson \& Hoza, 1993). The findings of this study confirm that parents/caregivers and teachers are indispensable informants on children's behavior (Konold et al., 2010) and they assess behavior 
differently (Bolsoni-Silva et al., 2006; Satake et al., 2003).

Teachers identified a greater number of social skills than parents/caregivers, which can be related to the school context as stated by Wiley, Siperstein, Forness, and Brigham (2010), who found that the school environment is a predictive variable for the behavior of children when using regression analysis. A second hypothesis is that mothers are more demanding in their assessments, as identified by Bolsoni-Silva et al. (2006), as they did not distinguish social skills among preschool children with and without problems, while teachers did.

\section{Final Considerations}

The study found that social skills differentiated children with and without behavior problems, irrespective of the years of education, while gender had strong discriminative power for teachers and less influence on the assessment of parents/ caregivers. Furthermore, we found that boys have more behavior problems and the years of education did not influence this repertoire.

The strong aspects of the present study were: (a) the assessment of social skills, differentiating children by behavior problems and gender, considering preschool and school-age children; (b) the use of family and school informants; (c) the use of diagnostic tools; and (d) the simultaneous assessment of social skills and behavior problems.

The limitations of the study were related to the study only taking place in one city in the state of São Paulo, making it difficult to generalize the results to other regions of the country as well as the use of self-reporting instruments.

By collecting data from the same sample, with parents and teachers as evaluators, we have filled a gap in the literature by pointing to peculiarities of child behavior that depends on the environment and evaluator. It is noteworthy that these data have implications for the assessment and intervention with preschool and school-age children and it may also foster new studies with larger and more diverse

462 samples.

\section{Contributors}

All authors contributed to the conception and design of the study, data analysis and final editing.

\section{References}

Achenbach, T. M., \& Rescorla, L. (2001). Aseba school-age forms \& profiles. Burlington: Aseba.

Bandeira, M., Rocha, S. S., Freitas, L. C., Del Prette, Z. A. P., \& Del Prette, A. (2006a). Habilidades sociais e variáveis sociodemográficas em estudantes do ensino fundamental. Psicologia em Estudo, 11(3), 541-549. http://dx.doi.org/10.1590/\$1413-7372200600030 0010

Bandeira, M., Rocha, S. S., Souza, T. M. P., Del Prette, Z. A. P., \& Del Prette, A. (2006b). Comportamentos problemáticos em estudantes do ensino fundamental: características da ocorrência e relação com habilidades sociais e dificuldades de aprendizagem. Estudos de Psicologia (Natal), 11(2), 199-208. http://dx.doi.org/ 10.1590/S1413-294X2006000200009

Barham, E. J., \& Cia, F. (2009). Repertório de habilidades sociais, problemas de comportamento, autoconceito e desempenho acadêmico de crianças no início da escolarização. Estudos de Psicologia (Campinas), 26(1), 45-55. http://dx. doi.org/10.1590/S0103-166X2009 000100005

Barreto, S. O., Freitas. L. C., \& Del Prette, Z. A. P. (2011). Habilidades sociais na comorbidade entre dificuldades de aprendizagem e problemas de comportamento: uma avaliação multimodal. Psico, 42(4), 503-510. http:// dx.doi.org/10.15448/1980-8623.2011.4.7593

Berry, D., \& O'Connor, E. (2010). Behavioral risk, teacherchild relationships, and social skill development across middle childhood: A child-by-environment analysis of change. Journal of Applied Developmental Psychology, 31(1), 1-14. http://dx.doi.org/10.1016/j.appdev.2009. 05.001

Bolsoni-Silva, A. T., Marturano, E. M., \& Freiria, L. R. B. (2010). Indicativos de problemas de comportamento e de habilidades sociais em crianças: um estudo longitudinal. Psicologia: Reflexão e Crítica, 23(3), 506-515. http://dx.doi.org/10.1590/S0102-797220100003 00011

Bolsoni-Silva, A. T., Marturano, E. M., \& Loureiro, S. R. (2009). Construction and validation of the brazilian Questionário de Respostas Socialmente Habilidosas segundo relato de professores (QRSH-PR). Spanish Journal of Psychology, 12(1), 349-359. http://dx. doi.org/10.1017/S1138741600001748

Bolsoni-Silva, A. T., Marturano, E. M., \& Loureiro, S. R. (2011). Estudos de confiabilidade e validade do Ques- 
tionário de Respostas Socialmente Habilidosas Versão para Pais - QRSH-Pais. Psicologia: Reflexão e Crítica, 24(2), 227-235. http://dx.doi.org/10.1590/S0102-797 22011000200003

Bolsoni-Silva, A. T., Marturano, E. M., \& Manfrinato, J. W. S. (2005). Mães avaliam comportamentos socialmente "desejados" e "indesejados" de pré-escolares. Psicologia em Estudo, 10(2), 245-252. http://dx. doi.org/10.1590/S1413-73722005000200011

Bolsoni-Silva, A. T., Marturano, E. M., Pereira, V. A., \& Manfrinato, J. V. S. (2006). Habilidades sociais e problemas de comportamento de pré-escolares: comparando avaliações de mães e de professoras. Psicologia: Reflexão e Crítica, 19(3), 460-469. http://dx.doi.org/ 10.1590/S0102-79722006000300015

Bordin, I. A. S., Mari, J. J., \& Caeiro, M. F. (1995). Validação da versão brasileira do "Child Behavior Checklist" (CBCL) (Inventário de Comportamentos da Infância e Adolescência): dados preliminares. Revista $A B P-A P A L$, $17(2)$, 55-66.

Cosentino-Rocha, L., \& Linhares, M. B. M. (2013). Temperamento de crianças e diferenças de gênero. Paidéia, 23(54), 63-72. http://dx.doi.org/10.1590/1982-43 272354201308

Karp, J., Serbin, L. A., Stack, D. S., \& Schwartzman, A. E. (2004). An observational measure of children's behavioural style: Evidence supporting a multi-method approach to studying temperament. Infant and Child Development, 13(2), 135-158. http://dx.doi.org/10. 1002/icd.346

Kettler, R. J., Elliott, S. N., Davies, M., \& Griffin, P. (2011). Testing a multi-stage screening system: Predicting performance on Australia's national achievement test using teachers' ratings of academic and social behaviors. School Psychology International, 33(1), 93-111. http:// dx.doi.org/10.1177/0143034311403036

Kim, M. J., Doh, H. S., Hong, J. S., \& Choi, M. K. (2010). Social skills training and parent education programs for aggressive preschoolers and their parents in South Korea. Children and Youth Services Review, 33(6), 838845. http://dx.doi.org/10.1016/j.childyouth.2010.12. 001

Konold, T. R., Jamison, K. R., Stanton-Chapman, T. L., \& Rimm-Kaufman, S. E. (2010). Relationships among informant based measures of social skills and student achievement: A longitudinal examination of differential effects by sex. Applied Developmental Science, 14(1), 18-34. http://dx.doi.org/10.1080/1088869090351 0307

Lambert, E. W., Wahler, R. G., Andrade, A. R., \& Bickman, L. (2001). Looking for the disorder in conduct disorder. Journal of Abnormal Psychology, 110(1), 110-123. http://dx.doi.org/10.1037/0021-843X.110.1.110

Landale, N. S., Lanza, S. T., Hillemeier, M., \& Oropesa, R. S. (2013). Health and development among Mexican, black and white preschool children: An integrative approach using latent class analysis. Demographic Research, 28(44), 1302-1338. http://dx.doi.org/10.4 054/DemRes.2013.28.44

Leman, P. J., \& Björnberg, M. (2010). Conversation, development, and gender: A study of changes in children's concepts of punishment. Child Development, 81(3), 958-971. http://dx.doi.org/10.1111/j.1467-86 24.2010.01445.x

Leme, V. B., \& Bolsoni-Silva, A. T. (2010). Habilidades sociais educativas parentais e comportamentos de pré-escolares. Estudos de Psicologia (Natal), 15(2), 161-173. http://dx.doi.org/10.1590/S1413-294X201000020 0005

Massola, G. M., \& Silvares, E. F. M. (2005). A percepção do distúrbio de comportamento infantil por agentes sociais versus encaminhamento para atendimento psicoterapêutico. Revista Interamericana de Psicología, 39(1), 139-150.

Melo, S. A., \& Perfeito, H. C. C. S. (2006). Características da população infantil atendida em triagem no período de 2000 a 2002 numa clínica-escola. Estudos de Psicologia (Campinas), 23(3), 239-249. http://dx.doi. org/10.1590/S0103-166×2006000300003

Miner, J. L., \& Clarke-Stewart, K. A. (2008). Trajectories of externalizing behavior from age 2 to age 9: Relations with gender, temperament, ethnicity, parenting, and rater. Developmental Psychology, 44(3), 771-786. http://dx.doi.org/10.1037/0012-1649.44.3.771

Olson, S. L., \& Hoza, B. (1993). Preschool developmental antecedents of conduct problems in children beginning school. Journal of Clinical Child Psychology, 22(1), 60-67. http://dx.doi.org/10.1207/s15374424jc cp2201_6

Pizato, E. C. G., Marturano, E. M., \& Fontaine, A. M. G. V. (2014). Trajetórias de habilidades sociais e problemas de comportamento no ensino fundamental: influência da educação infantil. Psicologia: Reflexão e Crítica, 27(1), 189-197. http://dx.doi.org/10.1590/S0102-79 722014000100021

Reynolds, M. R., Sander, J. B., \& Irvin, M. J. (2010). Latent curve modeling of internalizing behaviors and interpersonal skills through elementary school. School Psychology Quarterly, 25(4), 189-201. http://dx.doi. org/10.1037/a0021543

Samarakkody, D., Fernando, D., McClure, R., Perera, H., \& De Silva, H. (2012). Prevalence of externalizing behavior problems in Sri Lankan preschool children: Birth, childhood, and sociodemographic risk factors. Social Psychiatry and Psychiatric Epidemiology, 47(5), 757-762. http://dx.doi.org/10.1007/s00127-011-03 77-5

Satake, H., Yoshida, K., Yamashita, H., Kinukawa, N., \& Takagishi, T. (2003). Agreement between parents and 
teachers on behavioral/emotional problems in Japanese school children using the child behavior checklist. Child Psychiatry and Human Development, 34(2), 111-126. http://dx.doi.org/10.1023/A:1027342007736

Scortegagno, P., \& Levandowski, D. (2004). Análise dos encaminhamentos de crianças com queixa escolar da Rede Municipal de Ensino de Caxias do Sul. Interações, 9(18), 127-152.

Wielewicki, A. (2011). Problemas de comportamento infantil: importância e limitações de estudos de ca- racterização em clínicas-escola brasileiras. Temas em Psicologia, 19(2), 379-389.

Wiley, A. L., Siperstein, G. N., Forness, S. R., \& Brigham, F. J. (2010). School context and the problem behavior and social skills of students with emotional disturbance. Journal of Child Family Study, 19(4), 451-461. http:// dx.doi.org/10.1007/s10826-009-9316-4

Received: November 18, 2014

Final version: April 9, 2015

Approved: June 30, 2015 